\title{
ISM-CODE SEBAGAI UPAYA PERLINDUNGAN HUKUM DARI PENGGUNAAN KAPAL YANG TIDAK STANDAR KELAIKLAUTAN
}

\author{
Boby Asmarinanda ${ }^{1,}$ Nurmaya Safitri ${ }^{2}$ \\ Faculty of Law, Lambung Mangkurat University \\ Jalan Brigjen H.Hasan Basry, Banjarmasin 70123, Indonesia \\ Email: bobyasmarinanda12@gmail.com \\ Faculty of Law, Lambung Mangkurat University \\ Jalan Brigjen H.Hasan Basry, Banjarmasin 70123, Indonesia \\ Email: mayasafitri94@gmail.com
}

\begin{abstract}
Transportation in Indonesia is facing many challenges, but all the possibilities that will occur can be anticipated with a more robust National Transportation System Arrangement. This study aims to find out and understand the application of the ISM-Code used as legal protection from the use of ships which are not of seaworthiness standards. The research method used is a normative research method, which is a legal writing method that aims to obtain library legal materials by collecting and analyzing legal materials related to the problem. The results of this study, first. In the application of the ISM-Code is used as legal protection from the use of ships that are not standard for seaworthiness. There are still many Shipping Companies that issue policies that are not ISM-Code standards or do not meet the elements of Article 9 of the Transportation Ministerial Decree Number 45 of 2012 concerning Ship Safety Management Systems. And second, the ISM-Code Requirement as legal protection from the use of ships which are not standard of seaworthiness is from the form of legal protection contained in the ISM-Code.
\end{abstract}

Keywords: Internasional Safety Management Code; Legal Protection; Sea worthiness

\begin{abstract}
Abstrak
Transfortasi secara umum di Indonesia sedang menghadapi banyak tantangan, tetapi segala kemungkinan yang akan terjadi dapat diantisipasi dengan Penataan Sistem Transportasi Nasional yang lebih tangguh. Penelitian ini bertujuan untuk mengetahui dan memahami penerapan ISM-Code digunakan sebagai perlindungan hukum dari penggunaan kapal yang tidak standar kelaiklautan. Metode penelitian yang digunakan adalah metode penelitian normatif, yaitu suatu metode penulisan hukum yang
\end{abstract}


bertujuan untuk memperoleh bahan hukum pustaka dengan cara mengumpulkan dan menganalisis bahan hukum terkait dengan permasalahan. Adapun hasil penelitian ini, pertama. Dalam penerapan ISM-Code digunakan sebagai perlindungan hukum dari penggunaan kapal yang tidak standar kelaiklautan. Masih banyak Perusahaan Pelayaran yang mengeluarkan kebijakan yang tidak standar ISM-Code atau tidak memenuhi unsur Pasal 9 Permen Perhubungan Nomor 45 Tahun 2012 Tentang Sistem Manajemen Keselamatan Kapal. Dan kedua Diperlukannya ISM-Code sebagai perlindungan hukum dari penggunaan kapal yang tidak standar kelaiklautan ialah dari bentuk perlindungan hukum yang ada dalam ISM-Code tersebut.

Kata Kunci: Internasional Safety Management Code; Perlindungan Hukum; Kelaiklautan

\section{PENDAHULUAN}

Di dalam suatu pekerjaan apapun selalu terdapat risiko yang timbul dalam melakukan perbuatan untuk memenuhi tanggung jawab pada pekerjaan tersebut. Risiko itu bisa berupa kecelakaan kecil bahkan dapat berupa kecelakaan besar (parah). Sistem Manajemen Keselamatan Kerja baik keselamatan kerja di darat, di dalam tanah, di permukaan air, di dalam air, di udara dan dimanapun kegiatan pekerjaan itu dilakukan harus wajib selalu ada perusahaan yang menaunginya itu untuk memberikan kebijakan-kebijakan dalam hal Sistem Manajemen Keselamatan Kerja. Kebijakan penerapan keselamatan kerja bertujuan menciptakan budaya keselamatan dan kesehatan kerja (K3) ditempat kerja dengan melibatkan perusahaan, tenaga kerja, kondisi dan lingkungan kerja dalam rangka mencegah dan mengurangi kecelakaan dan penyakit akibat kerja.

Indonesia sebagai negara kepulauan adalah satu kesatuan yang tak terpisahkan antara darat, laut, dan udara. Secara fisik, laut adalah pemisah yang nyata antara pulau satu dengan yang lainnya. Oleh karena itu untuk mencapai pulau yang lain di butuhkan alat transportasi, dari segi kelautan adalah kapal laut. Dalam Pasal 310 KUHD menyebutkan "Kapal Laut adalah semua kapal yang dipakai untuk pelayaran di laut atau yang diperuntungkan untuk itu". Sebagai suatu sistem, transportasi laut yang merupakan bagian dari Sistem Transportasi Nasional didukung oleh elemen kegiatan angkutan laut, kepelabuhan, kelaiklautan kapal, kenavigasian serta penjagaan dan penyelamatan yang saling berinteraksi secara terpadu guna mewujudkan tersedianya angkutan laut yang efektif dan 
efisien. Transfortasi secara umum di Indonesia sedang menghadapi banyak tantangan, tetapi segala kemungkinan yang akan terjadi dapat diantisipasi dengan Penataan Sistem Transportasi Nasional (SISTRANAS) yang lebih tangguh. Ketangguhan yang dimaksud tidak terlepas dari pengawasan tiga hal yaitu alam, sumber daya manusia dan teknis. ${ }^{1}$

Akibat kelemahan pengawasan manajemen sistem transportasi laut di Indonesia. Maka Indonesia sedang dihadapkan pada kecelakaan-kecelakaan transportasi laut. Internasional Safety Management Code (ISM-Code) merupakan standar peraturan manajemen keselamatan internasional untuk keamanan maupun keselamatan pengoperasian kapal dan pencegahan pencemaran lingkungan laut yang ditetapkan oleh Dewan Keselamatan Maritim IMO. Tujuan ISM-Code adalah untuk menjamin keselamatan dilaut, mencegah kecelakaan dan hilangnya jiwa manusia serta menghindari kerusakan lingkungan khususnya lingkungan laut dan serta hilangnya harta benda. Perusahaan harus menyatakan secara tertulis kebijakannya (policy) tentang keselamatan dan perlindungan lingkungan maritim (kelautan) dan memastikan bahwa setiap

1 Arfianna Noverra. Upaya Mengatasi Kecelakaan Kapal Laut Berdasarkan UU No. 17 Tahun 2008 Tentang Pelayaran. 2008. "Makalah Diskusi”. Universitas Sriwijaya., hlm. 816. orang dalam perusahaan mengetahui dan memahaminya $^{2}$

Ketentuan Pasal 169 Bagian Ketujuh dari Undang-undang Nomor 17 Tahun 2008 Tentang Pelayaran tersebut, jelas bahwa perusahaan harus memenuhi persyaratan ISM-Code dalam pengoperasian Kapal di laut ataupun bagi perusahaan yang mengoperasikan kapal tersebut. Dalam kaitanya disini adalah pada perwujudan kebijakan ISM-Code itu sendiri. Aturan lanjutan dari Pasal 169 Undang-Undang Nomor 17 Tahun 2008 Tentang Pelayaran, diwujudkan dalam bentuk suatu Peraturan Perundangundangan tersendiri yang mengatur ISMCode secara kekhususan. Perwujudan ini berupa Peraturan Menteri Perhubungan Nomor 45 Tahun 2012 Tentang Manajemen Keselamatan Kapal.

\section{RUMUSAN MASALAH}

Berdasarkan latar belakang sebagaimana dijelaskan diatas, penulis tertarik mengupas beberapa pemasalahan yang dijadikan objek penelitian adalah sebagai berikut :

1. Bagaimana penerapan ISM-Code digunakan sebagai perlindungan

${ }^{2}$ Nina Nurhasanah, Asmar Joni, dan Nur Shabrina. Persepsi Crew Dan Manajemen Dalam Penerapan ISM-Code Bagi Keselamatan Pelayaran Dan Perlindungan Lingkungan Laut. 2015. "Seminar Nasional Multi Disiplin Ilmu Dan Call For Papers". Universitas Stikubank. Semarang., hlm. 1 
hukum dari penggunaan kapal yang tidak standar kelaiklautan ?

2. Mengapa ISM-Code diperlukan sebagai upaya perlindungan hukum dari penggunaan kapal yang tidak standar kelaiklautan?

\section{METODE PENELITIAN}

Berdasarkan pemasalahan yang akan diteliti, maka metode penelitian yang digunakan adalah metode penelitian normatif, metode penelitian hukum normatif yaitu suatu metode yang digunakan dengan cara mengumpulkan dan menganalisis bahan-bahan hukum yang berhubungan dengan permasalahan dalam penelitian ini. Bahan hukum yang digunakan terdiri dari bahan hukum primer, bahan hukum skunder dan bahan hukum tersier.

\section{PEMBAHASAN}

\section{Tinjauan Umum Tentang Kapal}

Kapal adalah sarana yang paling sering digunakan sebagai alat transportasi melalui air ini. Kapal pada umumnya digunakan sebagai sarana transportasi untuk menjalankan usaha. Baik menjadi Kapal membawa atau mengangkut barang, membawa atau mengangkut penumpang, bahkan dapat juga dapat berupa material hasil bumi (tambang) atau bahan kimia. Di dalam Pasal 309 KUHD merumuskan kapal sebagai "Kapal adalah semua perahu, dengan nama apapun, dan dari macam apapun juga". Pengertian kapal Vollmar berpendapat bahwa alat yang berlayar (vaartuig) adalah :

"Tiap benda yang dapat berlayar (yang dapat berpindah atau dapat dipindahkan di atas air) atau benda itu yang diperuntukkan buat berlayar. Demikian sehubungan dengan adanya galangan kapal terapung, pengeruk lumpur, penyedot pasir dll. Yang terapung diatas air, benda-benda tersebut tidak dapat bergerak sendiri, tetapi dapat digerakan walau tidak diperuntukkan sebagai demikian, tetapi mempunyai fungsi sebagai perahu (istilah terjemahan vaartuig dalam KUHD) yang berada disuatu tempat tertentu walaupun kadangkadang berpindah tempat menurut kebutuhan". 3

Lalu pada Pasal 1 butir 36 UndangUndang Nomor 17 Tahun 2008 Tentang Pelayaran, Undang-undang ini merumuskan pengertian kapal menjadi lebih jelas yaitu :

"Kapal adalah kendaraan air dengan bentuk dan jenis tertentu,

3 Wartini Soegeng. 1988. Pendaftaran Kapal Indonesia. Cet.I. Bandung : PT. Eresco, hlm. 6. 
yang digerakkan dengan tenaga angin, tenaga mekanik energi lainnya, ditarik atau ditunda, termasuk kendaraan yang berdaya dukung dinamis, kendaraan dibawah permukaan air, serta alat apung dan bangunan terapung yang tidak berpindah-pindah."

\section{Perlindungan Hukum Bagi Para Pekerja di Kapal}

Perlindungan hukum bagi tenaga kerja telah dijelaskan dalam Pasal 28 D ayat (2) UUD 1945 yang berbunyi "Setiap orang berhak untuk bekerja serta mendapatkan imbalan dan perlakuan yang adil dan layak dalam hubungan kerja".

Perlindungan hukum bagi para pekerja baik para pekerja yang bekerja di darat, di udara, dan di laut itu di mulai dari adanya hubungan hukum yaitu hubungan kerja antara Pemberi Kerja dengan Pekerja. Dalam Pasal 4 Undang-Undang Nomor 13 Tahun 2003 Tentang Ketenagakerjaan menyebutkan bahwa perlindungan hukum bagi tenaga kerja ini bertujuan untuk :

a. Memberdayakan dan mendaya gunakan tenaga kerja secara optimal dan manusiawi,

b. Mewujudkan pemerataan kesempatan kerja dan penyediaan tenga kerja yang sesuai dengan kebutuhan pembangunan nasional dan daerah,

c. Memberikan perlindungan kepada tenaga kerja dalam mewujudkan kesejahteraan, dan

d. Meningkatkan kesejahteraan tenaga kerja dan keluarganya.

\section{Gambaran Umum ISM-Code}

Dalam Ketentuan Umum Pasal 1 butir 2 Peraturan Menteri Nomor 45 Tahun 2012 Tentang Manajemen Keselamatan Kapal menyebutkan bahwa "International Safety Management (ISM) Code adalah Koda Internasional tentang Manajemen Keselamatan Pengoperasian Kapal dan Pencegahan Pencemaran sebagaimana yang diatur dalam Bab IX Konvensi SOLAS 1974 yang telah diamandemen". ISM-Code merupakan produk dari IMO yang akhirnya diadopsi oleh SOLAS pada tahun 1994. ISM-Code merupakan standar sistem Manajemen Keselamatan untuk pengoperasian kapal secara aman dan untuk pencegahan pencemaran di laut, ISM-Code ini bertujuan untuk menjamin keselamatan di laut, mencegah kecelakaan atau kematian, dan juga mencegah kerusakan pada lingkungan dan kapal. ${ }^{4}$

ISM-Code membentuk suatu standar international untuk manajemen dan operasi kapal yang aman dengan menetapkan aturan bagi perusahaan

${ }^{4}$ Andi Dachlan Sadly. Kompetensi Pelaut Dalam Penerapan International Safety Manajemen Code ISM-Code. 2015. "Jurnal Relasi STIE Mandala", Vol. 22., hlm.245. 
pelayaran sehubungan dengan keselamatan dan pencegahan polusi serta untuk penerapan Safety Manajemen System (SMS). SMS menjadi tulang punggung bagi perusahaan pada saat ditentukan dan didokumentasikan, tugas, dan aktivitas yang berkaitan dengan keselamatan dan perlindungan lingkungan, baik di darat maupun di kapal. Adanya peraturan pengoperasian kapal yang aman diharapkan dapat mencegah terjadinya kecelakaan kapal sehingga tidak merugikan perusahaan yang bersangkutan dan pengguna transportasi itu sendiri. Untuk itu diperlukan adanya dukungan dari perusahaan atas kebutuhan operasional kapal yang aman, perlindungan terhadap lingkungan, dan manajemen perusahaan yang baik dengan mengoptimalkan implementasi ISM-Code. ${ }^{5}$

\section{Penerapan ISM-Code Digunakan} Sebagai Perlindungan Hukum Dari Penggunaan Kapal Yang Tidak Standar Kelaiklautan

ISM-Code dibuat sebagai suatu koda atau petunjuk secara Internasional. Manajemen keselamatan kapal yang dibuat tersebut bertujuan untuk mengarahkan kepada perusahaan agar dapat memberikan suatu perlindungan hukum kepada kapal,

\footnotetext{
${ }^{5}$ Ibid., hlm. 246.
}

bukan hanya kepada kapal tetapi juga kepada para pekerja diatas kapal (awak kapal), peralatan diatas kapal, dan juga terhadap lingkungan kerja (lingkungan maritim). Dari semua keharusan yang dilakukan oleh Perusahaan yang berdasarkan ISM-Code tersebut haruslah adanya Pengawasan dalam penerapannya. ISM-Code di Indonesia telah diundangkan didalam suatu produk hukum yaitu pada Peraturan Menteri Perhubungan Nomor 45 Tahun 2012 Tentang Manajemen Keselamatan Kapal.

Sistem Manajemen Keselamatan dibuat dalam rangka pemenuhan terhadap persyaratan IMO dan Pemerintah Republik Indonesia melalui Direktorat Jendral Perhubungan Laut tentang Sistem Manajemen Keselamatan Kapal dan Perlindungan Lingkungan (ISM-Code). Sistem Manajemen Keselamatan ini diterapkan pada semua kegiatan yang berkaitan dengan pengoperasian kapal, termasuk pengoperasian kapal secara aman dan perlindungan terhadap pencemaran. ${ }^{6}$ Setiap kapal harus mempunyai sistem dan prosedur penanggulangan dan pencegahan terhadap peristiwa gangguan terhadap keselamatan (safety) dan dalam pelaksanaannya harus menunjuk seorang Perwira yang bertanggung jawab dalam melakukan pengawasan terhadap

\footnotetext{
${ }^{6}$ Ibid,
} 
keselamatan (safety) kapal dan pencegahan pencemaran dari kapal. ${ }^{7}$

Manajemen keselamatan kapal yang kurang memadai dari fungsi pengawasannya, dapat dilihat akibat kelemahan pengawasan manajemen sistem transportasi laut di Indonesia. Maka Indonesia sedang dihadapkan pada kecelakaan-kecelakaan transportasi laut. Sebanyak $80 \%$ kecelakaan kapal terjadi oleh kesalahan manusia, dari kesalahan manusia tersebut sebanyak $75 \%$ disebabkan oleh sistem manajemen yang buruk, untuk itu harus dibuat sistem manajemen yang mampu menciptakan kerjasama yang baik dan erat antara manajemen kapal dan manajemen darat. ${ }^{8}$ Hal seperti ini dapat kita jadikan sebagai tolak ukur bahwa penerapan manajemen keselamatan kapal di Indonesia masih kurang, apa lagi dari segi pengawasannya. Padahal dalam Peraturan Menteri Perhubungan Nomor 45 Tahun 2012 tentang Manajemen Keselamatan Kapal, sudah jelas tugas dan wewenang dari para pihak otoritas perusahaan, kapal, dan pemerintah.

${ }^{7}$ Nina Nurhasanah, Asmar Joni, dan Nur Shabrina. Persepsi Crew Dan Manajemen Dalam Penerapan ISM-Code Bagi Keselamatan Pelayaran Dan Perlindungan Lingkungan Laut. 2015. "Seminar Nasional Multi Disiplin Ilmu Dan Call For Papers". Universitas Stikubank. Semarang., hlm. 3 - 4

${ }^{8}$ Ibid, hlm. 1.
Perusahaan harus membuat peraturan dan kebijakan terkait manajemen perusahaan dan manajemen kapal yang sesuai standar ISM-Code atau Peraturan Manajemen Keselamatan Kapal. Bahwa maksud dan tujuan dari manajemen keselamatan kapal ialah "Menjamin bahwa kegiatan di atas kapal dibawah manajemen perusahaan memenuhi persyaratan dari Sistem Manajemen Keselamatan dan menjamin serta mempertahankan pelayaran kapal yang aman, memperhatikan keselamatan awak kapal, muatan, barang dengan membuat prosedur yang diperlukan". 9

Berikut penerapan yang disebutkan dalam International Safety Management Code (ISM-Code) pada Revised Edition 2010, dalam paragraf 1.3 dan 1.4, yaitu:

1.3.Persyaratan Koda ini dapat diterapkan pada semua kapal;

1.4. Persyaratan Sistem Manajemen Keselamatan (SMK); Setiap perusahaan harus mengembangkan, melaksanakan dan mempertahankan Sistem Manajemen Keselamatan (SMK) yang mencakup fungsi yang dipersyaratkan sebagai berikut: 1.4.1. Kebijakan keselamatan dan perlindungan lingkungan; 1.4.2. Instruksi dan prosedur untuk menjamin pengoperasian kapal yang aman dan perlindungan lingkungan sesuai dengan Peraturan Internasional dan Nasional yang berlaku; 1.4.3.Menentukan tingkat

9 MT. Kerta Dua. 2004. Manual Management Book : ISM-Code., hlm 1 
kewenangan dan jalur komunikasi antara dan sesama personil di darat dan di atas kapal; 1.4.4.Prosedur pelaporan kecelakaan dan ketidak sesuaian terhadap persyaratan dari koda ini; 1.4.5.Prosedur untuk persiapan dan penanggulangan keadaan darurat; dan 1.4.6.Prosedur audit internal dan tinjauan manajemen.

Dalam melakukan penerapan ISM-

Code digunakan sebagai perlindungan hukum bagi kapal yang tidak standar kelaiklautan tetapi tetap dioperasikan oleh perusahaan ini. Mengharuskan agar pengawasan dari semua pihak ditingkatkan agar mampu menjalankan tugas, wewenang dan tanggung jawab yang sesuai dengan undang-undang yang berlaku. Melalui kebijakan Perusahaan memenuhi unsur Pasal 9 Peraturan Menteri Perhubungan Nomor 45 Tahun 2012 tentang Manajemen Keselamatan Kapal, selanjutnya pelaporan yang dilakukan pihak diatas kapal kepada Perusahaan, setelah itu ada peran Syahbandar dalam mengawasi pemenuhan ISM-Code tersebut terkait kelaiklautan kapal dengan dibuktikan melalui penerbitan dokumen atau sertifikat. Sehingga dalam praktiknya pengawasan yang dilakukan Syahbandar jangan hanya melihat legal dokumennya saja dengan meminta orang lain sebagai agennya untuk memeriksa beberapa dokumen kapal agar dapat menerbitkan
SIB. Tanpa melihat kondisi kapal yang standar ISM-Code atau tidak dengan memperhatikan dokumen berdasarkan kelengkapan ISM-Code. Ini didasari atas koordinasian atau kerjasama yang baik dan sikap saling peduli khususnya kepada para pekerja di kapal dan lingkungan laut.

\section{ISM-Code Sebagai Perlindungan}

Hukum Dari Penggunaan Kapal Yang Tidak Standar Kelaiklautan

Dasar hukum ISM-Code ialah Pasal 169 Undang-Undang Nomor 17 Tahun 2008 Tentang Pelayaran dan diatur lanjuti oleh Peraturan Menteri yaitu Peraturan Menteri Perhubungan Nomor 45 Tahun 2012 Tentang Manajemen Keselamatan Kapal. ISM-Code merupakan suatu standar klaiklautan bagi kapal baik secara Nasional dan juga Internasional. Dalam halnya perlindungan hukum berarti berbicara hak dan kewajiban. Untuk menjamin keselamatan pelayaran, ISM-Code tidak hanya menjamin keselamatan bagi kapal namun juga awak kapalnya. Artinya hak dan kewajiban disini terkait hubungan kerja yang timbul dari Perusahaan Pelayaran ialah Majikan/Pemberi Kerja (pengusaha kapal) terhadap para pekerja/buruh (awak kapal) yang bekerja diatas kapal. Hubungan kerja ini dimulai dari adanya perjanjian kerja. Khususnya dalam pelayaran ialah Perjanjian kerja laut. 
Untuk mendapatkan perlindungan hukum yang dimaksud para Awak kapal dalam hubungan kerja dengan Pengusaha Kapal haruslah dimulai dari adanya Perjanjian Kerja Laut. Dalam Pasal 395 KUHD mendefinisikan Perjanjian kerja laut bahwa "Perjanjian kerja laut adalah perjanjian yang dibuat antara seorang pengusaha kapal disatu pihak dan seorang buruh dipihak lain, dengan mana pihak tersebut terakhir menyanggupi untuk di bawah perintah pengusaha melakukan pekerjaan dengan mendapat upah, sebagai Nahkoda atau anak buah kapal".

$$
\text { Pasal } 1338 \quad \text { KUHPerdata }
$$
menjelaskan bahwa "Semua perjanjian yang dibuat secara sah berlaku sebagai undang-undang bagi mereka yang membuatnya". Perjanjian dalam hukum perdata merupakan suatu yang mendasar dan dapat dikatan sebagai undang-undang bagi pembuatnya, dapat dikatakan bahwa perjanjian merupakan suatu bentuk perlindungan hukum bagi para pihak dalam melakukan perjanjian tersebut.

ISM-Code tidak akan berjalan dengan baik apabila tidak diterapkan sepenuhnya dan yang paling penting adalah fungsi pengawasan dari penerapan tersebut apakah sudah terpenuhi atau belum. Pengawasan merupakan bagian yang paling penting dalam Manajemen. Tanpa ada pengawasan dan kepeduliaan dari berbagai pihak maka tujuan atau rencana awal dari organisasi tersebut tidak dapat dicapai. ISM-Code atau Manajemen Keselamatan Kapal juga merupakan suatu perlindungan hukum bukan hanya bagi kapal namun juga awak kapalnya.

Adapun beberapa alasan untuk menjalankan ISM-Code di antaranya $:^{10}$

1. ISM-Code menjadikan kapal sebagai tempat yang aman untuk bekerja;

2. ISM-Code melindungi laut dan lingkungan/wilayah perairan;

3. ISM-Code mendefinisikan tugas dengan jelas;

4. ISM-Code adalah hukum.

Perlindungan hukum yang diberikan ISM-Code ialah mendefinisikan tugas para pihak dengan jelas, artinya hak dan kewajiban masing-masing pihak sudah di atur dalam manajemen keselamatan yang baik. Pada huruf $b$ dan d Pasal 9 Peraturan Menteri Perhubungan 45 Tahun 2012 Tentang Manajemen Keselmatan Kapal menyebutkan bahwa ada tanggung jawab dan wewenang yang dimiliki Pihak Otoritas di darat (Perusahaan) dan tanggung jawab dan wewenang oleh Pihak Otoritas di atas kapal (Nahkoda). Disamping mendefinisikan tugas dari

10 Djumadi. 2004. Hukum Perburuhan Perjajian Kerja. Cet V. Jakarta : PT. Raja Grafindo Persada., hlm. 88-89 
perusahaan ISM-Code juga menjamin agar perusahaan memberikan dukungan yang memadai terhadap para pekerjanya dukungan dapat berupa peralatan kerja yang baik dan jaminan sosial yang harus diberikan kepada para pekerja agar para pekerja dapat bekerja dengan aman dan sejahtera. Pasal 1 butir 2 Undang-Undang Nomor 24 Tahun 2011 tentang Badan Penyelenggara Jaminan Sosial menyatakan bahwa "Jaminan sosial adalah salah satu bentuk perlindungan sosial untuk menjamin seluruh rakyat agar dapat memenuhi kebutuhan dasar hidupnya yang layak".

Secara hukum tujuan ISM-Code atau Manajemen Keselamatan Kapal disebutkan sebagaimana yang telah dimaksud dalam Pasal 7 Peraturan Menteri Perhubungan Nomor 45 Tahun 2012 Tentang Manajemen Keselamatan Kapal menyebutkan bahwa tujuan dari sistem manajemen keselamatan untuk :

a. Menyediakan tata kerja yang praktis dalam pengoperasian kapal dengan aman dan lingkungan kerja yang aman,

b. Menilai semua identifikasi risiko terhadap kapal, personil, lingkungan dan menentukan aksi pencegahannya, dan

c. Meningkatkan keterampilan personil di darat dan di kapal di bidang manajemen keselamatan secara terus-menerus, termasuk kesiapan menghadapi situasi darurat terkait keselamatan dan perlindungan lingkungan.

Fungsi ISM-Code sebagai perlindungan hukum bagi kapal yang tidak standar kelaiklautan tetapi tetap dioperasikan oleh perusahaan tersebut dilihat berdasarkan tujuan ISM-Code itu sendiri. Bahwa ISM-Code mendefinisikan tugas antar pihak dengan jelas. Undangundang telah mengatur keharusan yang harus dilakukan dan dipenuhi oleh perusahaan pelayaran atau dapat disebut bahwa ISM-Code mendefinisikan tugas, kewenangan dan tanggung jawab masingmasing pihak serta menyebutkan hak yang harus diterima serta kewajiban yang harus dilakukan dalam hubungan kerja tersebut. Namun dalam hal ini aspek pengawasan juga tidak boleh ditinggalkan, pengawasan dilakukan guna efesiensi dan efektivitas dari Manajemen Keselamatan Kapal dapat berjalan dan diterapkan dengan baik.

Berdasarkan aspek-aspek tersebut ISM-Code merupakan standar manajemen internasional yang merupakan manajemen keselamatan yang harus diterapkan di kapal juga di perusahaan dengan tujuan $:^{11}$

1. Menjamin keselamatan kapal dan awak kapalnya.

2. Mencegah timbulnya kecelakaan dan korban jiwa diatas kapal.

3. Mencegah terjadinya pencemaran lingkungan, kerusakan lingkungan

${ }^{11}$ Nina Nurhasanah, Asmar Joni, dan Nur Shabrina. Op.cit., hlm. 3. 
dan kehilangan harta benda.

Sehingga dalam Pasal 8 Peraturan

Menteri Perhubungan Nomor 45 Tahun

2012 Tentang Manajemen Keselamatn

Kapal. Sistem manajemen keselamatan

tersebut harus menjamin :

a. Terpenuhinya peraturan dan aturan yang diwajibkan,

b. Koda, petunjuk, dan standar yang direkomendasikan oleh Organisasi Maritim Internasional

(International

Maritime

Organization/IMO), Pemerintah,

Badan Klasifikasi, Serta Organisasi

Industri Maritim yang berlaku ikut dipertimbangkan.

\section{PENUTUP}

Berdasarkan penjelasan diatas maka dapat diambil kesimpulan bahwa: Pertama, Dalam penerapan ISM-Code digunakan sebagai perlindungan hukum dari penggunaan kapal yang tidak standar kelaiklautan. Masih banyak Perusahaan Pelayaran yang mengeluarkan kebijakan yang tidak standar ISM-Code atau tidak memenuhi unsur Pasal 9 Peraturan Menteri Perhubungan Nomor 45 Tahun 2012 Tentang Sistem Manajemen Keselamatan Kapal. Penerapan ISM-Code dimulai dari kebijakan Perusahaan yang disebut dengan Keselamatan Pelayaran.

Kedua, Diperlukannya ISM-Code sebagai perlindungan hukum dari penggunaan kapal yang tidak standar kelaiklautan ialah dari bentuk perlindungan hukum yang ada dalam ISM-Code tersebut, yakni dari adanya pendefinisian tugas para pihak dengan jelas. Yang berarti adanya pembagian tugas, wewenang dan tanggung jawab masing-masing pihak diatas kapal dan perusahaan. Dari adanya pembagian tugas tersebut artinya ada suatu hubungan kerja yang membuat hak dan kewajiban masing-masing pihak akan menjadi jelas.

\section{DAFTAR PUSTAKA}

Buku

Andi Dachlan Sadly. Kompetensi Pelaut Dalam Penerapan International Safety Manajemen Code ISMCode. 2015. "Jurnal Relasi STIE Mandala", Vol. 22.

Arfianna Noverra. Upaya Mengatasi Kecelakaan Kapal Laut Berdasarkan UU No. 17 Tahun 2008 Tentang Pelayaran. 2008. "Makalah Diskusi". Universitas Sriwijaya., hlm. 816.

Djumadi. 2004. Hukum Perburuhan Perjajian Kerja. Cet V. Jakarta : PT. Raja Grafindo Persada

MT. Kerta Dua. 2004. Manual Management Book : ISM-Code.

Nina Nurhasanah, Asmar Joni, dan Nur Shabrina. Persepsi Crew Dan Manajemen Dalam Penerapan ISMCode Bagi Keselamatan Pelayaran Dan Perlindungan Lingkungan Laut. 2015. "Seminar Nasional Multi Disiplin Ilmu Dan Call For 
Papers". Universitas Stikubank. Peraturan Menteri Perhubungan Nomor 45 Semarang.

Wartini Soegeng. 1988. Pendaftaran Kapal Indonesia. Cet.I. Bandung : PT. Tahun 2012 tentang Manajemen Eresco, hlm. 6.

\section{Peraturan Perundang-Undangan}

Undang-Undang Dasar Negara Republik Indonesia 1945.

Kitab Undang-Undang Hukum Perdata (staatsblad 1847 : No 23).

Kitab Undang-Undang Hukum Dagang (staatsblad 1924 : No 557).

Undang-Undang RI Nomor 13 Tahun 2003 tentang Ketenagakerjaan.

Undang-Undang RI Nomor 17 Tahun 2008 tentang Pelayaran.

Undang-Undang RI Nomor 22 Tahun 2009 tentang Lalu Lintas dan Angkutan Jalan.

Undang-Undang RI Nomor 24 Tahun 2011 tentang Badan Penyelenggara Jaminan Sosial.

Peraturan Pemerintah Nomor 7 Tahun 2000 tentang Kepelautan.

Peraturan Menteri Perhubungan Nomor 34 Tahun 2012 tentang Organisasi dan Tata Kerja Kantor Kesyahbandaran Utama. 